\title{
PCaPC 造十字形架構の接合部せん断性状に及ぼすシース管による貫通孔の影響 EFFECT OF OPENINGS THROUGH SHEATH ON SHEAR BEHAVIORS
OF BEAM-COLUMN JOINT IN POST-TENSIONED PRECAST FRAME
}

\author{
山下海斗*, 篠原 保二**, 岸田慎司*** \\ Kaito YAMASHITA, Yasuji SHINOHARA and Shinji KISHIDA
}

\begin{abstract}
3-D finite element analyses were conducted on post-tensioned precast concrete frames to investigate the shear behaviors of beam-column joints having some openings through sheaths. The compressive damage and confining effect in the beam-column joints were numerically estimated based on the 3-D stress state. Analytical results indicated that the shear strength of the beam-column joint decreased considerably with increasing opening ratio without beams installed orthogonally. If, however, the orthogonal beams were installed, the shear strength of the beam-column joint increased by $20 \%$ and the decrease in shear strength due to opening was softened because a high confining pressure was generated.
\end{abstract}

Keywords: Beam-column joint, Post-tensioned precast, O pening, Shear behaviors, D egree of damage, Confining effect 柱梁接合部，ポストテンションプレキャスト，貫通孔，せん断挙動，損傷度，拘束効果

\section{1. はじめに}

プレキャストの柱と梁を部材内のシース管に通し配筋した PC 鋼 材で圧着接合する $\mathrm{PCaPC}$ 圧着工法は，圧着部に変形を集中させるこ とで架構全体の損傷を制御することができるとされている ${ }^{1)}$ 。さら に，シース管内にグラウト材を充填しないアンボンド PCaPC 圧着工 法を用いることで，一般的な PCaPC 構造と比較して，損傷制御に加 えて施工面でも優れた工法となる。しかし，アンボンドとすること でシース管内に空隙が生じ，結果的に部材内および柱梁接合部（以 下，接合部）内に断面（体積）久損が生じる。これにより，アンボ ンド PCaPC 造架構の接合部内の応力状態は, 鉄筋コンクリート造 (以

下， RC 造）の接合部より厳しくなることが予測される。

$\mathrm{RC}$ 造接合部の設計方法では, 接合部は直交梁を無視した平面十字 形の架構内にあるものと想定し，各方向に対して独立にせん断設計 を行う方法 ${ }^{2)}$ が採用されている。現行の設計法をアンボンド PCaPC 造の接合部に用いた場合，想定する平面架構の接合部に生じる空隙 を無視すると，シース管による欠損量および久損状況によってせん 断耐力を過大評価すると考えられる。実際に既往の実験 ${ }^{3)}$ ４４，5)，6) では，グラウト材を充填しない体積欠損率が大きなアンボンド型試 験体では，直交梁の拘束効果以上に断面欠損によるせん断応力の低 下が大きいとする知見が得られている。
前述の実験 ${ }^{3)}$ ， 4) に付随し，PCaPC 構造に対する解析的な研究 7)も 行われているが，接合部の空隙状況が応力伝達機構やプレストレス および直交梁による拘束効果，さらに破壊メカニズムに与える影響 に焦点を当てた研究は皆無である。そこで本報では，前述の既往研 究で用いられた平面十字形および立体内柱型試験体を対象とした三 次元有限要素解析を行い, 内部コンクリートの拘束効果とせん断圧 縮破壊に関係する尺度 ${ }^{8}$ ，9）(等価拘束圧と損傷度）を用いて，空隙 を有する接合部のせん断伝達メカニズムを明らかにすることを目的 としている。なお，本報においては，接合部全体積（接合部有効幅 ×梁せいメ柱せい）に対して接合部内のシース管が占める割合（シ 一ス管の外径を用いて算出）を体積欠損率として定義し，接合部体 積の欠損状況を表す指標として使用する。

\section{2. 解析概要}

\section{1 対象試験体概要}

Table 1 に解析対象とした試験体の諸元, Fig. 1 に試験体の形状 と寸法を示す。なお, 試験体名は既往文献から変更しているため, 文献 6) 内での試験体名は Table 1 の（）内に示している。柱断面は $350 \mathrm{~mm} \times 350 \mathrm{~mm}$, 梁断面は $250 \mathrm{~mm} \times 400 \mathrm{~mm}$, 梁芯から柱頭加力点お よび柱脚ピンまではそれぞれ $1415 \mathrm{~mm}$ ，柱芯から両梁端ピン位置ま

\footnotetext{
* 東京工業大学環境理工学創造専攻 大学院生

** 東京工業大学未来产業技術研究所 准教授・博士(工学)

*** 芝浦工業大学工学部建築学科 教授・博士 (工学)
}

Grad Student, Dept. of Environmental Sci. and Tech., Tokyo Institute of Technology Assoc. Prof., Laboratory for FIRST, Tokyo Institute of Technology, Dr. Eng. Prof., Dept. of Architecture, Faculty of Engineering, Shibaura Institute of Technology, Dr. Eng. 
Table 1 List of test specimens

\begin{tabular}{|c|c|c|c|c|c|c|c|c|}
\hline \multicolumn{2}{|c|}{ Designation } & BP0 (H1) & BS0 (R2) & UP6 (P6) & US8 (R1) & US12 (R5) & UP12-2 (P7) & UP12-4 (P8) \\
\hline \multicolumn{2}{|l|}{ Joint type } & Cruciform & Interior joint & Cruciform & Interior joint & Interior joint & Cruciform & Cruciform \\
\hline \multicolumn{2}{|l|}{ PC type } & \multicolumn{2}{|c|}{ Bonded } & \multicolumn{5}{|c|}{ Unbonded } \\
\hline \multicolumn{2}{|c|}{ Volume loss ratio } & \multicolumn{2}{|c|}{$0 \%$} & $6.1 \%$ & $7.9 \%$ & \multicolumn{3}{|c|}{$12.1 \%$} \\
\hline \multicolumn{2}{|l|}{ Grout } & \multicolumn{2}{|c|}{$74.6 \mathrm{~N} / \mathrm{mm}^{2}$} & \multicolumn{5}{|c|}{ None } \\
\hline \multirow{2}{*}{$\begin{array}{c}\text { Sheath } \\
\text { (No. of pipes / Dia.*) }\end{array}$} & EW dir. & $2 / \varphi 55$ & $2 / \varphi 55$ & $2 / \varphi 68$ & $2 / \varphi 55$ & $2 / \varphi 68$ & $2 / \varphi 68$ & $2 / \varphi 68$ \\
\hline & NS dir. & None & $2 / \varphi 55$ & None & $2 / \varphi 55$ & $2 / \varphi 68$ & $2 / \varphi 68$ & $4 / \varphi 48$ \\
\hline \multicolumn{2}{|c|}{ PS tendons $(\varphi 36)$} & \multicolumn{2}{|c|}{ SBPD930 / 1080} & SBPR1080 / 1230 & SBPR930 / 1080 & \multicolumn{3}{|c|}{ SBPR1080 / 1230} \\
\hline \multicolumn{2}{|c|}{ Prestressing ratio $* *$} & 0.13 & $\begin{array}{l}0.14(\mathrm{EW}) \\
0.15(\mathrm{NS})\end{array}$ & 0.15 & $\begin{array}{l}0.14(\mathrm{EW}) \\
0.14(\mathrm{NS})\end{array}$ & $\begin{array}{c}0.17(\mathrm{EW}) \\
0.17(\mathrm{NS})\end{array}$ & 0.13 & 0.15 \\
\hline \multicolumn{2}{|c|}{ Common factor } & \multicolumn{3}{|c|}{$\begin{array}{l}\text { - Axial load ratio: } 0.13 \\
\text { - Cross section of column: } 350 \mathrm{~mm} \times 350 \mathrm{~mm} \\
\text { - Cross section of beam: } 250 \mathrm{~mm} \times 400 \mathrm{~mm} \\
\text { - Thickness of joint mortar: } 20 \mathrm{~mm}\end{array}$} & $\begin{array}{l}\text { - Longitudina } \\
\text { - Transverse } 1 \\
\text { - Longitudina } \\
\text { - Transverse } 1 \\
\text { - Transverse } 1\end{array}$ & $\begin{array}{l}\text { bars of column } \\
\text { rs of column: } 2 \\
\text { pars of beam: } 4 \\
\text { rs of beam: } 2-\mathrm{I} \\
\text { rs of joint: } 2-\mathrm{D}\end{array}$ & $\begin{array}{l}\text { 12-D25(SD490 } \\
\text { D10(SD345)@ } \\
\text { D13(SD345) } \\
10(\text { SD345)@10 } \\
0(\text { KSS785) }\end{array}$ & \\
\hline
\end{tabular}

*Outer diameter of sheath $\quad * *$ Prestressing force / (Cross-sectional area of beam $\times$ Compressive strength of concrete)

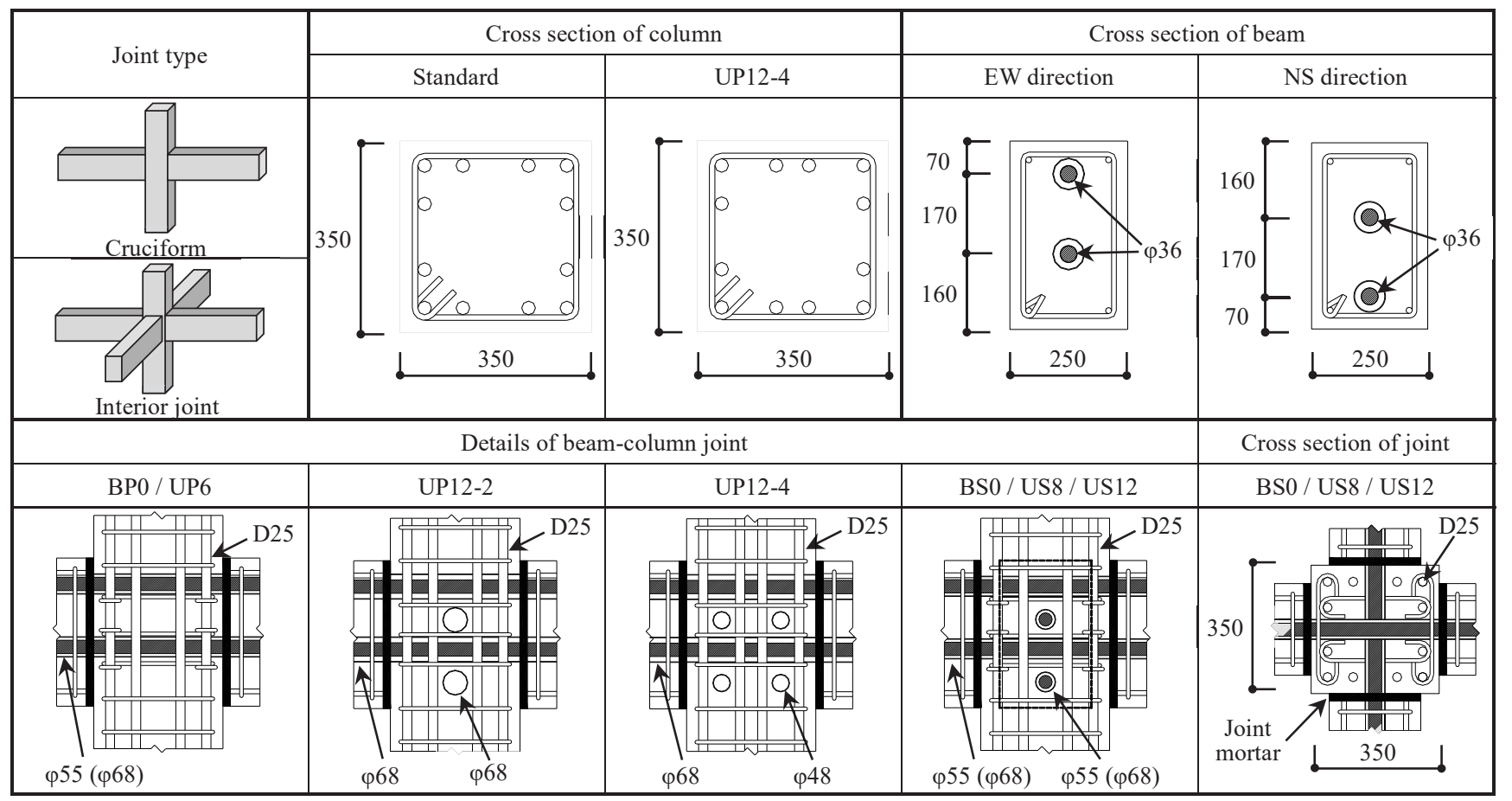

Fig. 1 Details of test specimens (Unit: $\mathrm{mm}$ )

では $1600 \mathrm{~mm}$ であり,これらは全試験体で共通である。また, 一連 の研究は PCaPC 造柱梁接合部のせん断性状の把握を目的として行わ れてきたため，接合部破壊が先行するよう，柱に使用したコンクリ 一トの圧縮強度（Table 3 参照）は梁の $1 / 2$ 程度となっている。こ こで立体試験体 BSO は, 直交梁による拘束効果を確認するためにボ ンド型の平面試験体 BP0 に直交梁が取り付いた試験体である。試験 体 US8（体積欠損率 8\%）は試験体 BS0 をアンボンドとしたものであ り，試験体 US12（体積欠損率 12\%）は，試験体 BS0，US8 に対して体 積欠損率の増加が接合部せん断性状に及ぼす影響を検討することを 目的としている。試験体 UP12-4 は試験体 UP12-2 と同様の体積欠損 率であるが，直交方向に小さな径のシース管を 4 本配することで開 孔を分散させ，開孔状況が接合部せん断性状に及ぼす影響を検討す

\section{るための試験体となっている。}

Table 2 に, 実験における加力スケジュールを示す。全試験体で 共通して, 梁端はローラー支持, 柱脚はピン支持とし, 上柱加力点 に水平 2 方向および鉛直方向の計 3 基のジャッキを取り付けた。柱 に軸力比 0.13 に相当する一定圧縮軸力を加えた後, 層間変形角 $R$ に よる変位制御で水平力を与え, 平面十字形の試験体は西方向を正, 東方向を負として正負交番繰り返し載荷を行った。層間変形角は, 上柱加力点での水平変位を, 加力点と柱脚ピン間の距離で除した值 としている。また，立体内柱型の試験体に関しては，最初の 1 サイ クルは西 $\rightarrow$ 東 $\rightarrow$ 南 $\rightarrow$ 北の順に $R=0.25 \%$ ず載荷し，その後はFig. 2 に示す加力パスにしたがって田の字形載荷を行った。なお, 解析結 果との比較には, 西方向（1)方向）加力時のデータを用いている。 
Table 2 Loading schedule

\begin{tabular}{|c|c|c|c|c|c|}
\hline Joint type & \multicolumn{4}{|c|}{ Cruciform } & Interior joint \\
\hline Loading method & \multicolumn{4}{|c|}{ Cyclic loading } & Bi-directional cyclic loading \\
\hline Rotation angle & BP0 & UP6 & UP12-2 & UP12-4 & BS0 / US8 / US12 \\
\hline $0.25 \%$ & \multicolumn{4}{|c|}{1 cycle } & $\begin{array}{c}1 \text { cycle } \\
\text { (One directional loading) }\end{array}$ \\
\hline $0.5 \%$ & \multicolumn{5}{|c|}{2 cycles } \\
\hline $1 \%$ & \multicolumn{5}{|c|}{2 cycles } \\
\hline $1.5 \%$ & & & & cles & None \\
\hline $2 \%$ & \multicolumn{5}{|c|}{2 cycles } \\
\hline $3 \%$ & & $1 \mathrm{cy}$ & & 2 cycles & 1 cycle \\
\hline $4 \%$ & \multicolumn{4}{|c|}{2 cycles } & 1 cycle \\
\hline
\end{tabular}

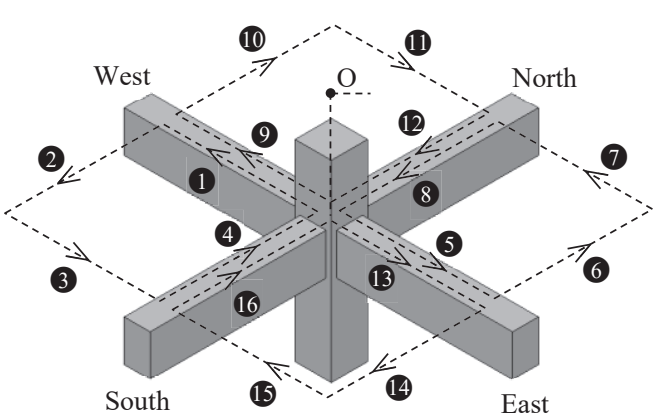

Fig. 2 Loading path (Bi-directional cyclic loading)

\section{2 解析モデル}

平面十字形シリーズ（以下，P シリーズ）の例として試験体 UP124, 立体十字形シリーズ（以下，S シリーズ）の例として試験体 US8 の要素分割および境界条件を Fig. 3 に示す。実験試験体の鋼製治 具に対応する柱頭, 柱脚および梁端部（Fig. 3 の灰色部分）は，鋼 材の弾性係数 $2.05 \times 10^{5} \mathrm{~N} / \mathrm{mm}^{2}$ を有する線形要素とした。コンクリ 一トおよび目地モルタルは, P シリーズでは 20 節点直方体要素, $\mathrm{S}$ シリーズでは 8 節点直方体要素でモデル化した。PC 鋼棒は 2 節点卜 ラス要素とし, 鉄筋には主筋, 横補強筋ともに完全付着を仮定した 埋め込み鉄筋要素を用いた。また, ボンド型の試験体 BP0 および BS0 の $\mathrm{PC}$ 鋼棒に関しては, トラス要素とコンクリート要素の間に節点イ ンターフェースを配置し，付着すべりを考慮した。柱部材と梁部材 の間には, 圧縮力のみを伝達する厚みを持たない界面要素を配置し, 圧着型 $\mathrm{PCaPC}$ 部材の特徵である圧着接合面の目開きを許容した。

ボンド型試験体は, 初めに $\mathrm{PC}$ 鋼棒に所定のプレストレスを与え, 順に, 付着特性, 柱軸力, 梁端ローラー支持を作用させた後, 柱頭 に強制変位を与えた。なお，アンボンド型試験体は付着要素を用い ていないため, 上記の過程から付着特性の作用を除いたものとなる。 また，試験体が鉛直軸（ $z$ 軸）回りに回転しないよう，西梁および東 梁端部のローラー支持点では，梁と直交方向（南北方向）の水平変 位を拘束した。加力については，Pシリーズ， S シリーズともに 1 方 向（西方向）単調載荷とした。

\section{3 構成モデル概要}

本解析で使用したコンクリートおよび目地モルタルの材料特性を Table 3，Fig. 4 に示寸。柱コンクリートの圧縮応力上昇部分には Popovics モデルを使用し, 圧縮強度経験後は線形軟化すると仮定し た。梁コンクリートおよび目地モルタルは高強度材料であるため, Popovics モデルを高強度領域にまで適応させた修正 Popovics モデ ル 10) を使用し，柱と同様に圧縮強度以降は線形軟化を仮定した。な お，圧縮強度時ひずみについては，材料試験の結果を用いた。圧縮 領域には Drucker-Prager の破壊基準を採用し, 内部摩擦角は柱コン クリート，梁コンクリートについてそれぞれ $20^{\circ} ， 15^{\circ}$ とした ${ }^{11)}$, 12)。引張領域には Rankine の最大引張応力基準による Tensioncutof ${ }^{13)}$ を採用し, 引張軟化特性には破壊エネルギーを $0.1 \mathrm{~N} / \mathrm{mm}$ と するバイリニアモデル ${ }^{14)}$ を用いた。ひび割れには分散ひび割れモデ ルを用い，主ひずみの方向が第 1 ひび割れの方向から $60^{\circ}$ 以上回転

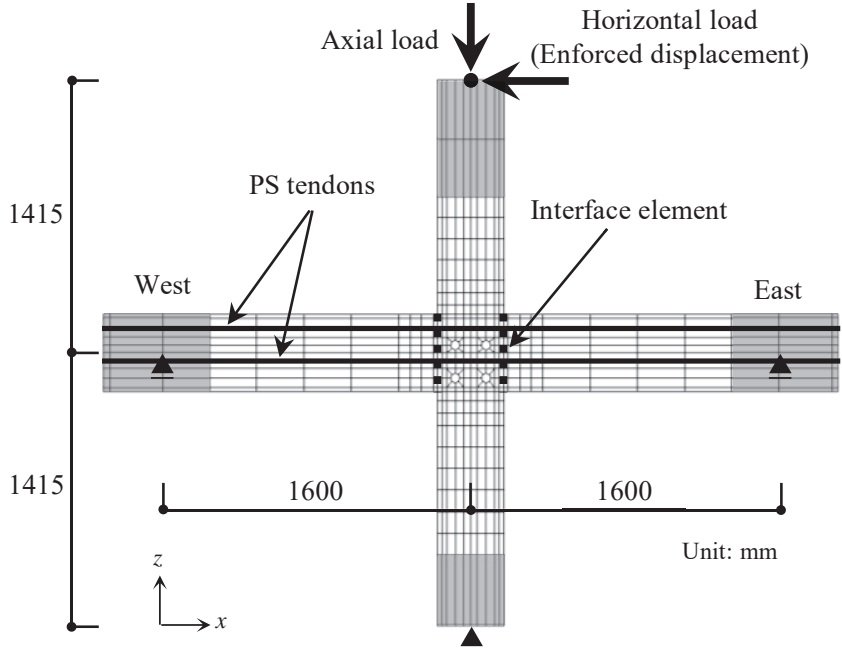

(a) Cruciform model (Specimen UP12-4)

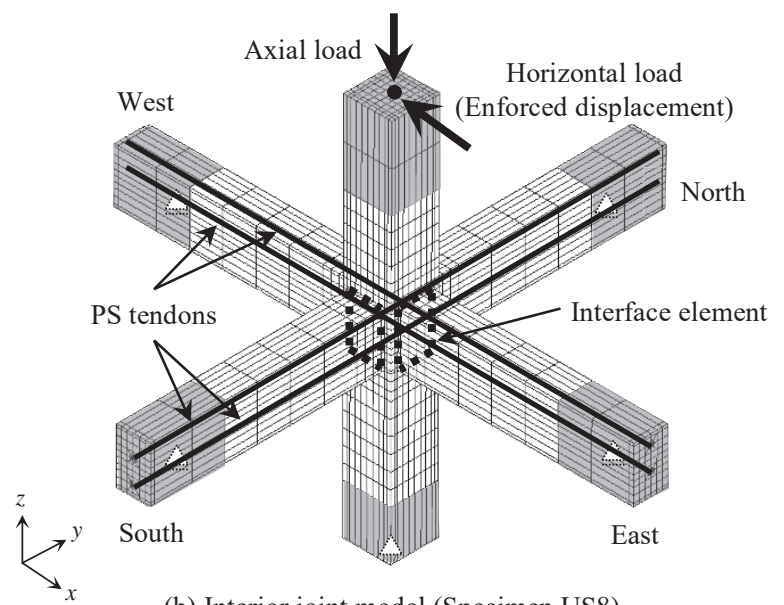

(b) Interior joint model (Specimen US8)

Fig. 3 Finite element models and boundary conditions

したときに第 2 ひび割れを発生させる過程を繰り返す, 多方向固定 ひび割れモデルを使用した。ひび割れ発生後のせん断剛性の低下に ついては，ひび割れひずみの関数 ${ }^{15)}$ としている。

また, 鋼材の材料特性を Table 4, Fig. 5 に示す。鋼材の応力一 ひずみ関係はバイリニア型とし, ひずみ硬化を考慮して降伏後の剛 性を初期剛性の $1 / 1000$ とした。鉄筋, PC 鋼棒ともに, 降伏条件は 
Table 3 Mechanical properties of concrete and mortar

\begin{tabular}{|c|c|c|c|c|c|c|c|}
\hline $\begin{array}{c}\text { Test } \\
\text { series }\end{array}$ & $\begin{array}{c}\sigma_{\mathrm{B}} \\
\mathrm{N} / \mathrm{mm}^{2}\end{array}$ & $\begin{array}{c}\varepsilon_{\max } \\
\times 10^{-6} \\
\end{array}$ & $\begin{array}{c}\mathrm{E}_{\mathrm{c}} \\
\times 10^{4} \mathrm{~N} / \mathrm{mm}^{2} \\
\end{array}$ & $\begin{array}{c}\sigma_{\mathrm{t}} \\
\mathrm{N} / \mathrm{mm}^{2}\end{array}$ & $\begin{array}{c}\mathrm{W}_{1} \\
\mathrm{~mm}\end{array}$ & $\begin{array}{l}W_{2} \\
\mathrm{~mm}\end{array}$ & $v$ \\
\hline \multicolumn{8}{|c|}{ Column } \\
\hline BP0 & 44.4 & 2153 & 3.24 & 2.7 & 0.033 & 0.165 & \multirow{6}{*}{0.2} \\
\hline $\begin{array}{c}\text { UP6 } \\
\text { US12 }\end{array}$ & 32.1 & 1895 & 2.78 & 2.8 & 0.032 & 0.159 & \\
\hline UP12-2 & 31.3 & 1686 & 2.53 & 2.2 & 0.040 & 0.202 & \\
\hline UP12-4 & 36.9 & 2471 & 2.61 & 3.2 & 0.028 & 0.139 & \\
\hline BS0 & 41.8 & 2130 & 3.37 & 3.4 & 0.026 & 0.131 & \\
\hline US8 & 45.4 & 2313 & 3.19 & 2.7 & 0.033 & 0.165 & \\
\hline \multicolumn{8}{|c|}{ Beam } \\
\hline BP0 & 82.7 & 2880 & 4.17 & 4.1 & 0.022 & 0.108 & \multirow{5}{*}{0.2} \\
\hline $\begin{array}{c}\text { UP6 } \\
\text { US12 }\end{array}$ & 67.1 & 2420 & 3.69 & 3.9 & 0.023 & 0.114 & \\
\hline $\begin{array}{l}\text { UP12-2 } \\
\text { UP12-4 }\end{array}$ & 81.3 & 2518 & 3.89 & 3.3 & 0.027 & 0.135 & \\
\hline BS0 & 75.5 & 2390 & 4.34 & 4.3 & 0.021 & 0.103 & \\
\hline US8 & 85.5 & 2970 & 3.97 & 4.0 & 0.022 & 0.111 & \\
\hline \multicolumn{8}{|c|}{ Mortar } \\
\hline $\begin{array}{l}\text { BP0 } \\
\text { BS0 } \\
\text { US8 }\end{array}$ & 74.6 & 5940 & 2.31 & 3.1 & 0.029 & 0.143 & \multirow{4}{*}{0.2} \\
\hline $\begin{array}{c}\text { UP6 } \\
\text { US12 } \\
\end{array}$ & 70.9 & 5794 & 2.40 & 3.5 & 0.025 & 0.875 & \\
\hline UP12-2 & 94.0 & 3415 & 3.66 & 7.4 & 0.012 & 0.060 & \\
\hline UP12-4 & 57.9 & 4152 & 1.94 & 3.9 & 0.023 & 0.114 & \\
\hline
\end{tabular}

$E_{c}$ : Young's modulus of concrete

$v$ : Poisson's ratio
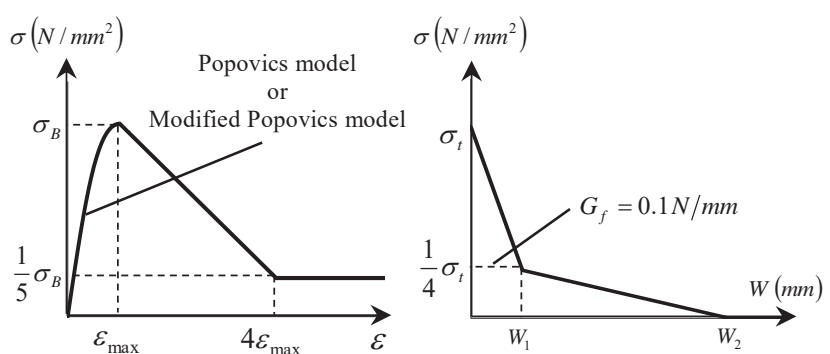

Compressive stress-strain curve

Tensile stress-crack width curve

Fig. 4 Analytical model for concrete and mortar

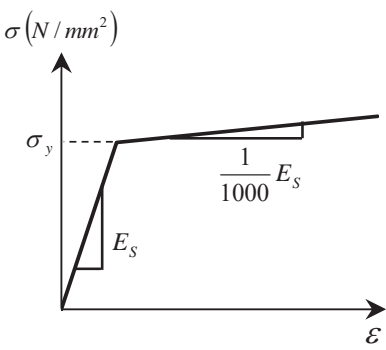

Fig. 5 Analytical model for reinforcement

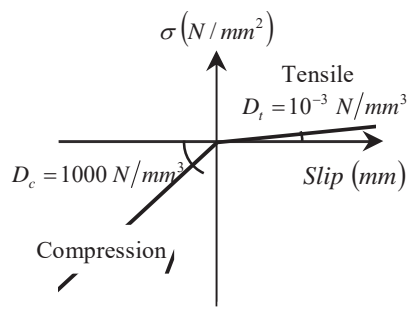

Stress-slip curve for normal direction

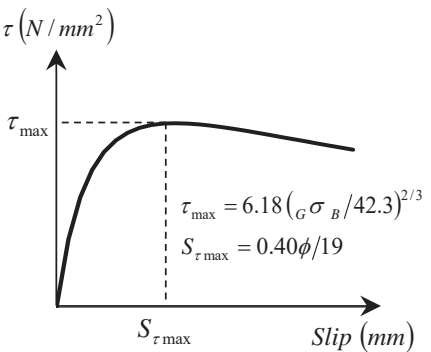

Fig. 6 Bond-slip model for PS tendons

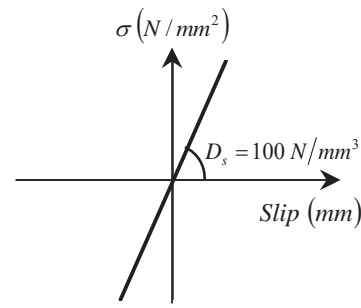

Stress-slip curve for shear direction
Fig. 7 Analytical model for interface elements

Table 4 Mechanical properties of reinforcement

\begin{tabular}{|c|c|c|c|c|c|c|c|c|c|c|}
\hline \multirow{2}{*}{ Designation } & \multicolumn{2}{|c|}{$\begin{array}{l}\text { Longitudinal bars } \\
\text { (Column) }\end{array}$} & \multicolumn{2}{|c|}{$\begin{array}{c}\text { Transverse bars } \\
\text { (Column) }\end{array}$} & \multicolumn{2}{|c|}{$\begin{array}{c}\text { Transverse bars } \\
\text { (Beam-column joint) }\end{array}$} & \multicolumn{2}{|c|}{$\begin{array}{c}\text { Longitudinal bars } \\
\text { (Beam) }\end{array}$} & \multicolumn{2}{|c|}{ PS tendons } \\
\hline & $\begin{array}{c}\sigma_{\mathrm{y}} \\
\mathrm{N} / \mathrm{mm}^{2}\end{array}$ & $\begin{array}{c}\mathrm{E}_{\mathrm{s}} \\
\times 10^{3} \mathrm{~N} / \mathrm{mm}^{2}\end{array}$ & $\begin{array}{c}\sigma_{\mathrm{y}} \\
\mathrm{N} / \mathrm{mm}^{2}\end{array}$ & $\begin{array}{c}\mathrm{E}_{\mathrm{s}} \\
\times 10^{3} \mathrm{~N} / \mathrm{mm}^{2}\end{array}$ & $\begin{array}{c}\sigma_{\mathrm{y}} \\
\mathrm{N} / \mathrm{mm}^{2}\end{array}$ & $\begin{array}{c}E_{s} \\
\times 10^{3} \mathrm{~N} / \mathrm{mm}^{2} \\
\end{array}$ & $\begin{array}{c}\sigma_{\mathrm{y}} \\
\mathrm{N} / \mathrm{mm}^{2}\end{array}$ & $\begin{array}{c}\mathrm{E}_{\mathrm{s}} \\
\times 10^{3} \mathrm{~N} / \mathrm{mm}^{2}\end{array}$ & $\begin{array}{c}\sigma_{\mathrm{y}} \\
\mathrm{N} / \mathrm{mm}^{2}\end{array}$ & $\begin{array}{c}\mathrm{E}_{\mathrm{s}} \\
\times 10^{3} \mathrm{~N} / \mathrm{mm}^{2}\end{array}$ \\
\hline $\mathrm{BP} 0$ / BS0/ US8 & 508 & 185 & 372 & 179 & 1010 & 181 & 369 & 169 & 1143 & 208 \\
\hline UP6 / US12 & 538 & 188 & 364 & 176 & 942 & 175 & 352 & 170 & 1169 & 211 \\
\hline UP12-2 & 542 & 196 & 371 & 187 & 1009 & 196 & 379 & 193 & 1119 & 203 \\
\hline UP12-4 & 551 & 192 & 370 & 179 & 914 & 177 & 379 & 193 & 1152 & 201 \\
\hline
\end{tabular}

Von Mises の条件を採用した。ボンド型試験体における PC 鋼棒とグ ラウト間の付着特性には，異形鉄筋とコンクリートの付着を対象と した森田らのモデル16)をグラウト材の圧縮強度を考慮できるよう改 良した, Fig. 6 に示寸是永らのモデル ${ }^{17)}$ を用いた。

圧着面での目開きを簡便に再現するため，柱梁間の圧着面インタ ーフェースには Fig. 7 に示寸非線形弾性モデルを使用した。法線 方向では圧縮側で剛性 $D_{c}$ の弾性体とし, 引張側で剛性をほぼ 0 とす ることで，圧縮力のみを負担するようにした。また，圧着目地部で のせん断すべり破壊は生じなかったため, せん断方向に対しては剛 性 $D_{s}$ の弾性挙動となるよう設定した。なお，材料特性の妥当性につ いては 3.1 節で後述する。

\section{3. 解析結果}

\section{1 層せん断カー層間変形角関係}

Fig. 8 に, 実験結果と解析結果の層せん断力一層間变形角関係を 比較して示す。最大耐力に関してはいずれの試験体も解析結果は過 大評価となり，最大で 17\%（UP6），最小で 2\%（UP12-2），実験結果を 上回った。また，全体的に変形を過小評価する傾向が見られる。こ れらの要因として，1)負載荷でのひび割れを考慮していないこと, 2) S シリーズの実験では 2 方向載荷を行ったが，解析では 1 方向単 調載荷としていることが考えられる。

図中にロマーカーでプロットしている点は接合部中央部でせん断 ひび割れが確認された点であり，P シリーズの実験では目視でひび 
割れを確認した点, 解析においてはFig. 9 に示寸接合部内中央部 のせん断補強筋のひずみが急増した時点をひび割れ発生点としてい る。なお，直交梁を有する S シリーズに関しては実験中に接合部パ ネルを観察することが難しいため，実験における接合部せん断ひび 割れの発生点は，解析と同じく接合部内補強筋のひずみが急増する 点（例えば試験体 US12 の実験值では， $73 \mu$ から $102 \mu$ に増加）で 判断した。試験体 UP6 を除くと, P シリーズの解析結果では接合部 せん断ひび割れの発生荷重を過小評価しているが，これは接合部内 部の補強筋位置のコンクリートが最初に損傷を受け，次にひび割れ が接合部表面に現れることを示している。

Fig. 8 の試験体 UP12-4 の解析結果には, 圧着面の界面要素に摩 擦要素を用いた場合のQ-R曲線を灰色線で示している。摩擦係数は PC 規準を参考に 0.5 とした ${ }^{18)}$ 。この摩擦モデルを用いた解析結果 （灰色）は非線形弾性モデルを使用した場合とほぼ一致しており, 本解析で使用したせん断剛性の妥当性が確認できたため, 数值計算 の安定性を考慮して非線形弾性モデルを全試験体に採用した。解析 上の破壊過程としては全ての試験体において，接合部せん断ひび割 れに先行して柱危険断面位置に曲げひび割れが発生するが，接合部 ひび割れの発生後は, 剛性の低下を伴って接合部ひび割れが拡張し た。

開孔のない試験体（BP0 と BSO）を比較すると, 最大耐力時の変形 角およびその後の破壊過程はほぼ同様であるが，コンクリート強度 の低いBS0 の方が高い耐力を保持しており，明らかに 3 方向からの 拘束効果がみられる。また, 同程度のコンクリート強度と開孔を有 する試験体（BP12-2，4 と BS12）を比較すると，立体試験体 BS12 の 変形性能（最大耐力とそのときの変形角）は平面試験体に対して, 実験においても解析においても向上していることがわかる。なお， 最大耐力後, 急激な荷重低下を引き起こさなかった平面試験体 BP0 と立体試験体の解析が実験結果を追随できたのは, 開孔を有する平 面試験体より高い拘束効果によってコンクリートの急激な膨張・ひ び割れが抑えられ，解析で使用した分散ひび割れモデルと整合性の ある挙動となったためと考えられる。これについては, 3.2 節のひ び割れ性状, 4.2 節と 4.3 節の 3 次元応力状態に基づいて詳述する。

Fig. 10 に, 試験体 BP0 の最大層せん断力を基準とした場合の, 各試験体の最大層せん断力の増減を示す。なお，試験体間で柱コン クリート強度が異なるため, 勒性指針の接合部せん断強度推定式 ${ }^{2)}$ を参考に, 最大層せん断力を基準化した值 $\left(=Q_{\max } / \sigma_{B}{ }^{0.712}\right)$ で比較し た。白抜きのプロットが実験結果, 黒塗りのプロットが解析結果を 示している。P シリーズでは実験と解析の両者において，体積欠損 率の増大とともに最大耐力が線形的に低下寸る傾向が見られ，試験 体 UP6 の最大耐力は無開孔の試験体 BP0 に対して, 実験と解析の両 者において約 15\%低下した。また，さらに体積欠損率の大きな試験 体 UP12-2 および UP12-4 は, 試験体 BP0 に対して約 30\%最大耐力が 低下したが，各試験体の最大耐力とそのときの層間変形角を比較し ている Table 5 からわかるように, 最大耐力時の層間変形角は試験 体 UP12-4 が UP12-2 を上回っている。S シリーズの 3 試験体の比較 では，試験体 US8 の最大耐力は無開孔の試験体 BS0 に対して約 25\% 低下しているが, 試験体 US12 は試験体 US8 と比較して体積欠損率が 大きく, かつ柱コンクリート強度が小さいにも関わらず，実験と解 析の両者において試験体 US8 の最大耐力を上回っている。これはコ

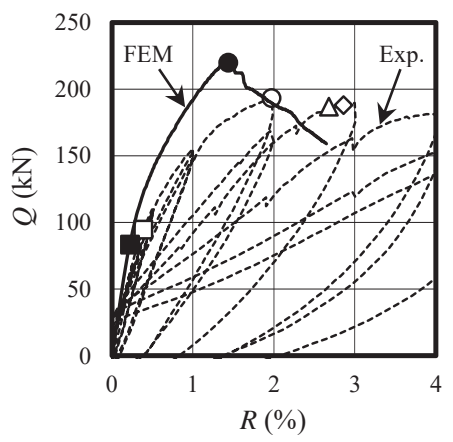

(1) BP0

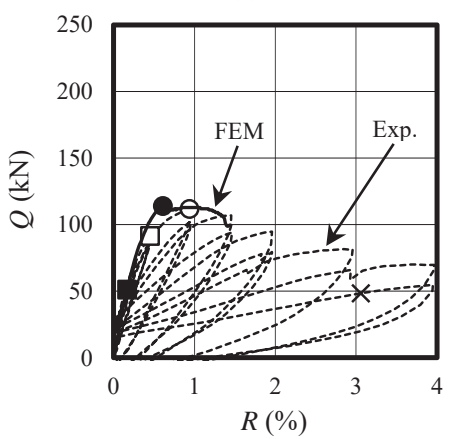

(3) UP12-2

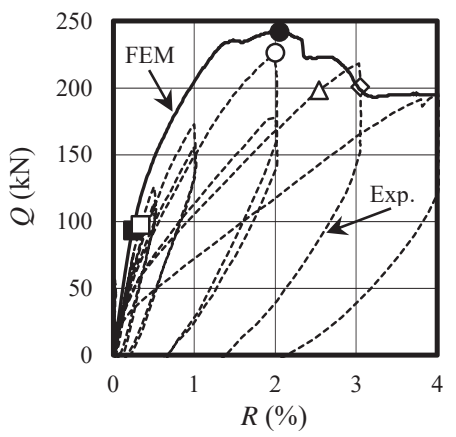

(5) BSO

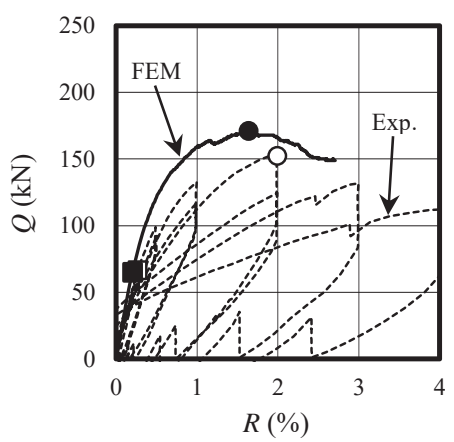

(7) US12

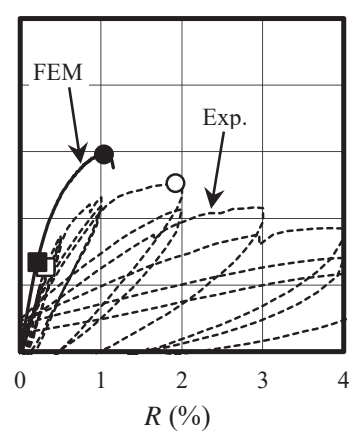

(2) UP6

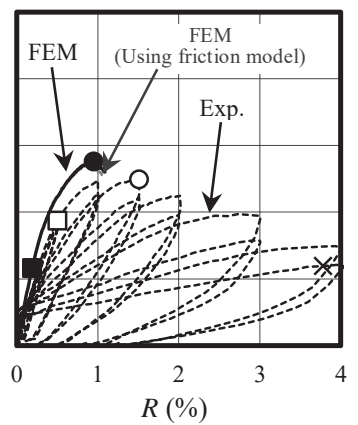

(4) UP12-4

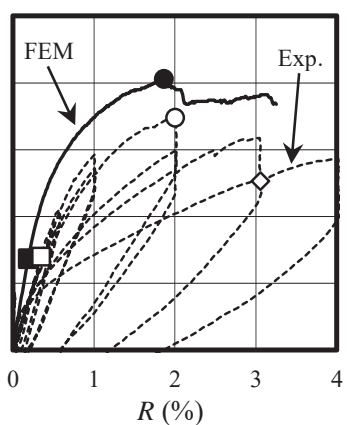

(6) US8 $\mathbf{\square}$ : Initiation of shear cracking at beam-column joint

- Maximum strength

$\Delta$ : Yielding of PS tendon

$\checkmark$ : Yielding of longitudinal bar of column

$\times$ : Yielding of transverse bar of beam-column joint

Fig. 8 Comparison between analytical and experimental shear force versus drift angle curves

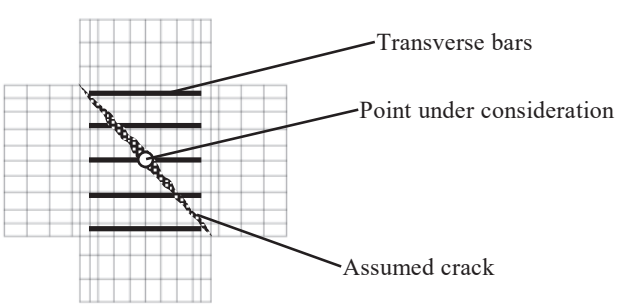

Fig. 9 Evaluation point for initiation of shear cracking at beam-column joint 
ンクリート強度が高いほど横拘束による圧縮強度増大の程度が減少 すること ${ }^{12)}$ ，さらにP シリーズより大きな拘束効果が生じる S シリ ーズ (Fig. 17 参照) では, コンクリート強度の影響が小さくなる ことに起因していると思われる。実際に, 各試験体の最大層せん断 力を試験体 BP0 の最大層せん断力で除した值と体積欠損率の関係を

Fig. 11 に示すが， S シリーズについてはコンクリート強度を考慮 しない場合，体積欠損率の増大に伴って線形的に耐力が低下してい く傾向が見られる。すなわち, 設計式 ${ }^{2)}$ のコンクリート強度の影響 は，平面試験体に基づいて考慮されているが，接合部の拘束状況に よって異なることが予想される。

Fig. 10 において同一の体積欠損率で P シリーズと S シリーズを 比較すると, 直交梁を有する無開孔の試験体 BS0 の最大耐力は試験 体 BP0 と比較して実験では $22 \%$, 解析では $15 \%$ 上昇した。また, 体積 久損率が 12\%である試験体 UP12-2, UP12-4, US12 で比較すると, 直 交梁を有する試験体 US12 の最大耐力は, 平面十字形の 2 試験体と 比較して実験では約 35\%, 解析では約 40\%上昇した。故に, 直交梁に よる拘束効果は無開孔のボンド型試験体よりも開孔を有するアンボ ンド型試験体でより明確に発揮されたといえる。

\section{2 ひび割れ性状}

Fig. 12 は, 最大耐力時における試験体 BP0, UP12-2, UP12-4, US12 のひび割れ状況について, 上側に実験結果のひび割れ図を, 下 側に解析結果のひび割れひずみコンター図（濃い部分がひび割れの 大きな領域）を示したものである。なお，コンター図は柱表面に最 も近い積分点におけるひび割れひずみを示している。

無開孔の試験体 BP0 は接合部中央にひび割れが発生した後, 接合 部パネルの対角方向に向かってひび割れが進展し, 最終的には接合 部内の広い領域でひび割れが発生した。これに対し, 開孔を有する 試験体UP12-2 およびUP12-4 は, 接合部中央のひび割れに先行して, 開孔中心から斜め方向のひび割れが発生した。その後, UP12-2 は開 孔間にひび割れが発生し，そのひび割れが集中的に成長した。一方 試験体 UP12-4 は，Fig. 12 に示す開孔 A および B 周囲のひび割れ が，実験と同様に連結するようにして接合部対角方向にひび割れが 発生した。試験体 US12 については, 直交梁が取り付く領域の近傍

(Fig. 12 の領域 A およびB）に大きなひび割れが発生したが，この ような傾向は S シリーズの 3 試験体に共通して見られ, 接合部中央 は直交梁の拘束効果によって膨張が抑えられるが, 拘束のない領域 はP シリーズの接合部と同様に膨張するため, ひび割れひずみが接 合部中央よりも大きくなった。ただし, S シリーズの中でも試験体

Table 5 Comparison of maximum capacity and rotation angle at $Q_{\max }$

\begin{tabular}{|c|c|c|c|c|}
\hline Designation & $\begin{array}{c}\exp _{\max } \\
(\mathrm{kN})\end{array}$ & $\begin{array}{c}\mathrm{R}_{\text {exp }} \\
(\%)\end{array}$ & $\begin{array}{c}\text { FEM } Q_{\max } \\
(\mathrm{kN})\end{array}$ & $\begin{array}{c}\mathrm{R}_{\text {FEM }} \\
(\%)\end{array}$ \\
\hline BP0 & 193 & 1.97 & 220 & 1.43 \\
\hline UP6 & 126 & 2.00 & 148 & 1.04 \\
\hline UP12-2 & 112 & 0.94 & 114 & 0.61 \\
\hline UP12-4 & 124 & 1.51 & 138 & 0.95 \\
\hline BS0 & 226 & 2.00 & 242 & 2.14 \\
\hline US8 & 174 & 2.00 & 203 & 1.86 \\
\hline US12 & 152 & 1.99 & 171 & 1.64 \\
\hline
\end{tabular}

$\exp _{\max }$ : Maximum capacity by experiment, feM $Q_{\max }$ : Maximum capacity by FEM $R_{\text {exp }}$ : Rotation angle at $Q_{\max }$ by experiment, $R_{F E M}$ : Rotation angle at $Q_{\max }$ by FEM
UP12-2 と同じ開孔状況である試験体 US12 は，試験体 UP12-2 と同様 に開孔間にも大きなひび割れが発生した。

\section{3 接合部内補強筋のひずみ分布}

Fig. 13 に, 体積欠損率が同一である試験体 UP12-2, UP12-4, US12 の接合部内補強筋のひずみ分布を示す。解析におけるひずみは, ひ ずみゲージ位置近傍の積分点の值を用いており, 実験結果を点線と 白抜きのプロット, 解析結果を実線と黒叙りのプロットで示してい

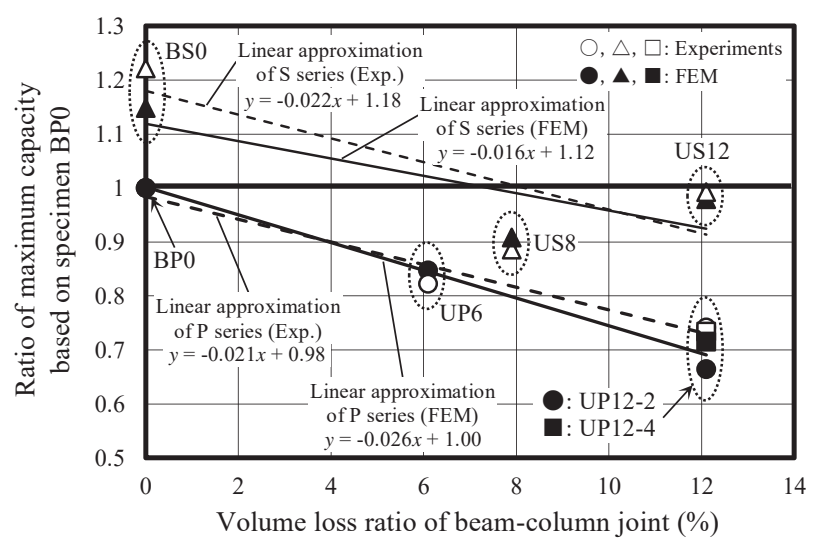

Fig. 10 Comparison of maximum capacity based on $Q_{\max } / \sigma_{B}{ }^{0.712}$

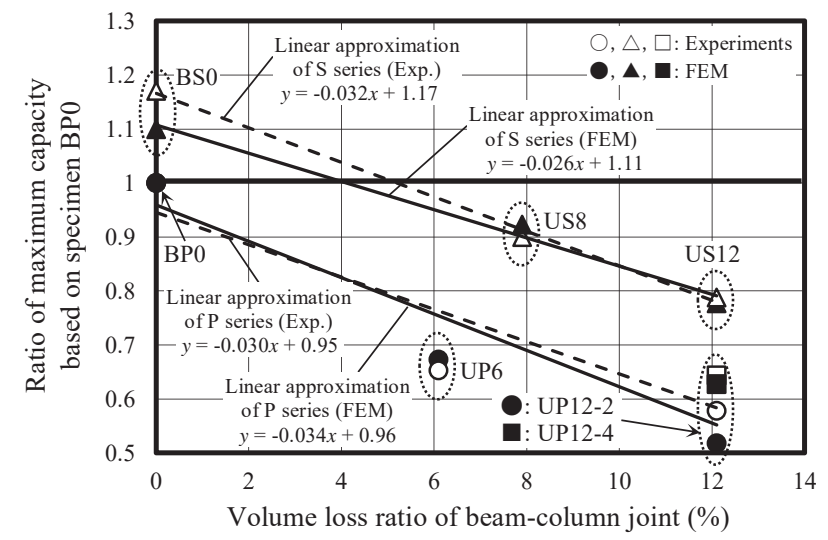

Fig. 11 Comparison of maximum capacity based on $Q_{\max }$
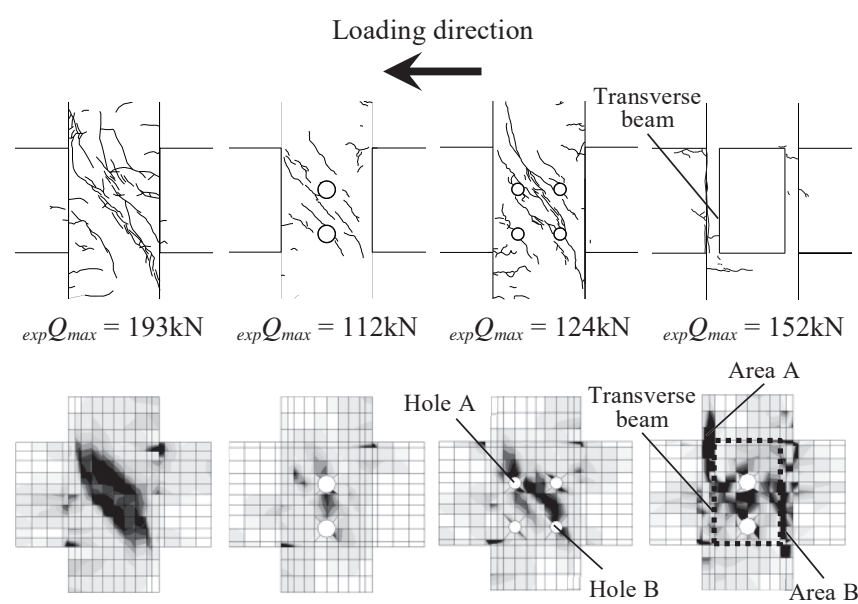

Area A

$\mathrm{FEM}_{\text {max }}=220 \mathrm{kN} \quad \mathrm{FEM}_{\max }=114 \mathrm{kN} \quad \mathrm{FEM}_{\max }=138 \mathrm{kN} \quad \mathrm{FEM} Q_{\max }=171 \mathrm{kN}$

(1) BP0

(2) UP12-2

(3) UP12-4

(4) US12

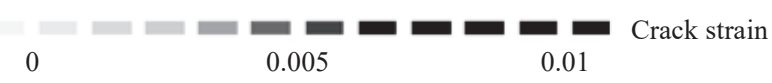

Fig. 12 Crack patterns of experiments and analyses at $Q_{\max }$ 
る。全試験体において実験結果と解析結果は概ね良好に対応してお り, 接合部南側においてひび割れの成長とともに腹部の補強筋 (HC3) のひずみが卓越する等の特徴も捉えているが, 試験体 US12 の接合部 東西面ついては，R=1\%時および $2 \%$ 時に解析値が実験值を大きく下回 る箇所が存在する。これは加力方法の違いに起因するものであり, 実験における南方向加力時に発生したひび割れの残留分を解析上で 表現できないためであると考えられる。開孔状況が同一である試験 体 UP12-2 および US12 の，R=0.5\%時の解析における HC3 のひずみを 比較すると, 試験体 US12 が試験体 UP12-2 に対して西面と東面の両 面で $100 \mu$ 程度, 南面で $600 \mu$ 程度小さくなった。このことから, 加力方向と直交方向に対する補強筋の拘束力は直交梁の有無に関わ らず同程度であるが，加力方向に対する補強筋の負担水平力は直交 梁の拘束により小さくなっていると考えられる。

\section{$3.4 P C$ 鋼棒のひずみ挙動}

接合部の変形およびひび割れの拡張に伴い, PC 鋼棒のひずみは増 大していくと考えられる。Fig. 14 に, 試験体 UP12-2, UP12-4, US12

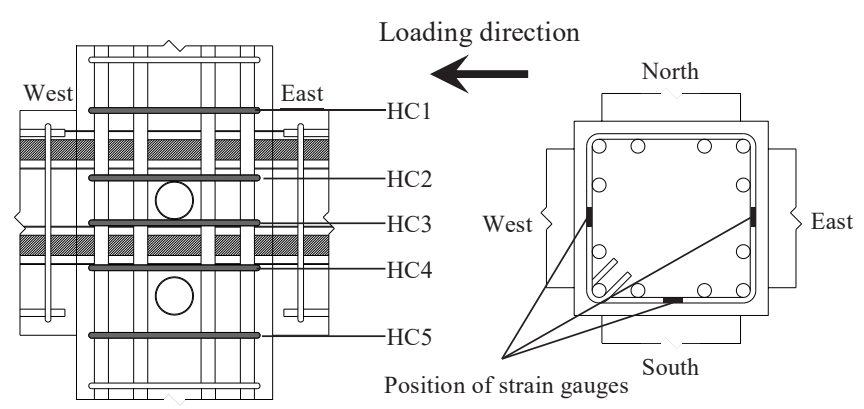

(a) Elevation

(b) Section

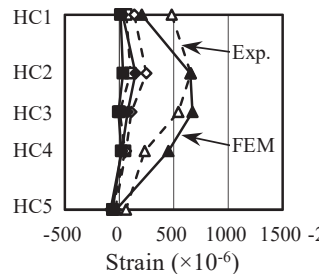

(a) West

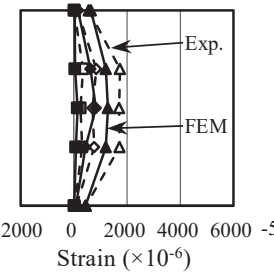

(b) South

(1) UP12-2

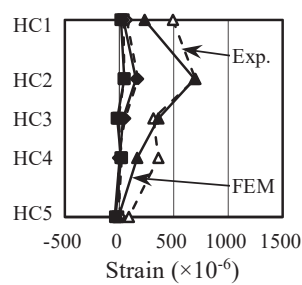

(a) West

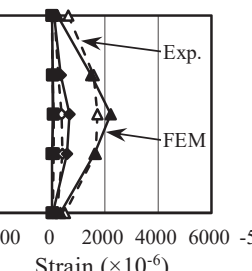

(b) South

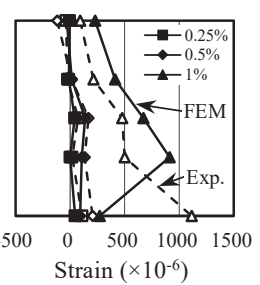

(c) East

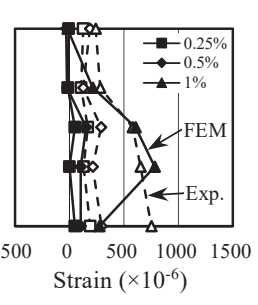

(c) East

(2) UP12-4

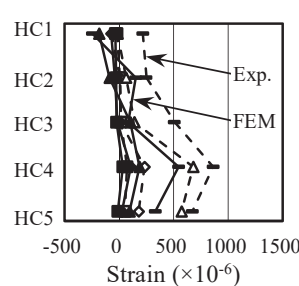

(a) West

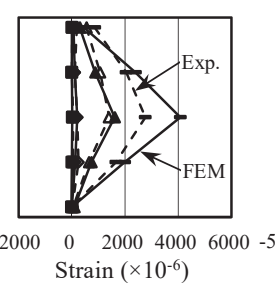

(b) South

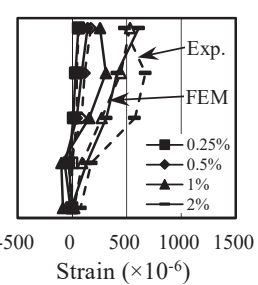

(c) East

(3) US12

Fig. 13 Strain distribution of transverse reinforcements of joints

の最大耐力時までの PC 鋼棒のひずみ挙動を示す。なお, 実験值は PC 鋼棒に貼付したひずみゲージの值の平均值である。プレストレス導 入から実験までの期間が試験体間で異なるため，水平力導入前のひ ずみが実験值と解析值で $200 \mu$ 程度異なる部分があるが，ひずみの 増分挙動はほぼ同じ傾向である。また，上端と下端で PC 鋼棒のひず みが異なっているが，これは上下非対称配筋であることに起因して いる。3 試験体とも, 東西方向に配した PC 鋼棒は水平力の増加に伴 いひずタが増大するが，試験体 US12 の南北方向の PC 鋼棒は水平力 に関わらずほぼ一定のひずみを保っている。このことから，接合部 に対する加力方向への拘束力が変形に伴って漸増するのに対し, 直 交方向に対しては拘束力の上昇は起こっていないことがわかる。

\section{4. 接合部における内部応力状態の検討 \\ 4.1 最小主応力分布}

Fig. 15 に, P シリーズ試験体 BP0, UP12-2, UP12-4 の最大耐力時 における最小主応力分布を変形 (変形倍率: 5 倍) と合わせて示す。 S シリーズ試験体についても, 最小主応力はより小さくなるが同様 の分布となる。なお, 切断面はFig. 15 の上部に示寸接合部中央付 近としている。無開孔の試験体 BP0 は接合部内で幅広く一様な圧縮 ストラットを形成しているが, 開孔を有する試験体 UP12-2 および UP12-4 は, 開孔によって圧縮ストラットが分断されることで, 接合 部内対角方向で圧縮応力を負担していない領域が存在している。3.1 節で述べたアンボンド型試験体の耐力低下は, このような圧縮ス卜 ラットの分断により圧縮応力の伝達領域が狭まることに起因してい ると考えられる。また, いずれの試験体も接合部内においては梁付 け根付近で圧縮応力が最も大きくなり, 柱コンクリート強度の 3 倍 以上の圧縮応力となる領域もあるが, 拘束状態が良好であるため （4. 2 節参照）1軸圧縮強度を超えても圧壊に至っていない。

\section{2 等価拘束圧}

プレストレスによる接合部コンクリートの拘束効果の尺度として, 水野らによる等価拘束圧の概念 ${ }^{8)}$ を用いる。等価拘束圧は, ランダ ムな応力経路上の一般応力状態を側圧一定の三軸圧縮実験経路上の 応力状態に換算した場合の側圧とする。Fig. 16 に等価拘束圧の概
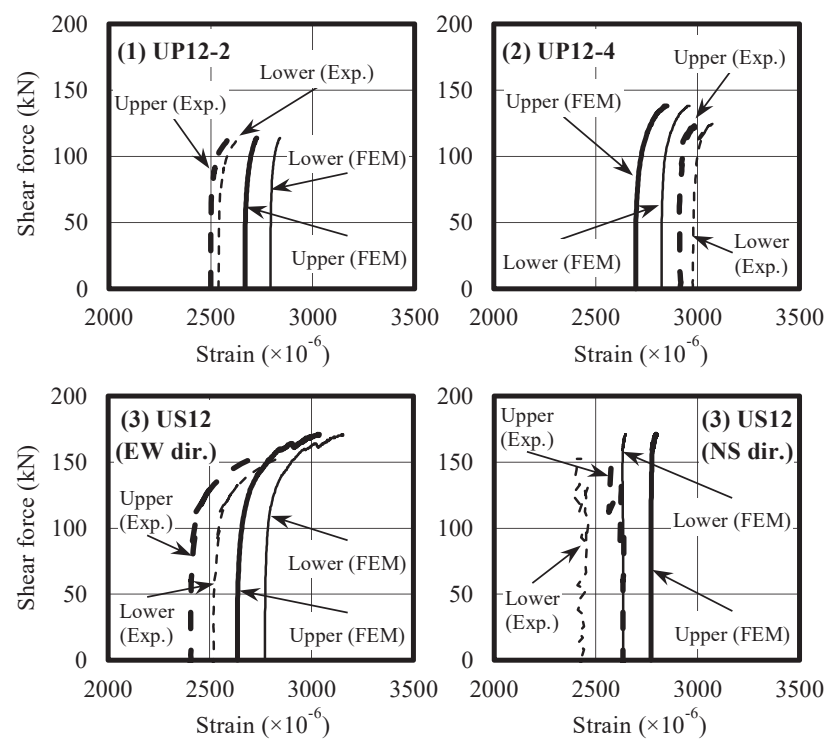

Fig. 14 Shear force versus strain of PS tendons curves 
念図を示す。ここで， $\xi$ と $r$ は一般応力状態を主応力空間で表示し た場合, 各々静水圧成分と偏差応力成分に相当する。一般応力点 $\mathrm{A}$ を側圧一定の三軸圧縮試験として, Fig. 16 の左図のような主応力 状態を考える場合, $\xi-r$ 平面上の A 点の座標は次のようになる。

$$
\begin{aligned}
& \xi=I_{1} / \sqrt{3}=\left(3 \sigma_{\mathrm{c}}+\sigma_{\mathrm{z}}\right) / \sqrt{3} \\
& \mathrm{r}=\sqrt{2 \mathrm{~J}_{2}}=\sqrt{2 / 3} \sigma_{\mathrm{z}}
\end{aligned}
$$

ただし， $I_{1}$ は応力の一次不変量， $J_{2}$ は偏差応力の二次不変量であ る。それ故, 応力点 $\mathrm{A}$ の等価拘束圧は, 傾き $-\sqrt{2}$ の直線と静水圧軸 との交点 B の静水圧 $\left(\sigma_{c}, \sigma_{c}, \sigma_{c}\right)$ となる。したがって, 3 主応力 が等しい状態で増加すると等価拘束圧も増大寸るが, 静水圧成分 $\xi$ が同じであっても 3 主応力の差が大きくなると, すなわち偏差応力 成分 $r$ が増加すると等価拘束圧は減少する。

Fig. 17 に, 最大耐力時における接合部の等価拘束圧を比較して 示す。等価拘束圧は，Fig. 17 内に示寸接合部表面および接合部内 部の切断面（A-A' 断面と $B-B$ ' 断面）に最も近い積分点における応 力状態より算出しているが, 試験体間でコンクリート圧縮強度が異 なるため, 側圧を 1 軸圧縮強度で基準化して示している。全試験体 において, 梁から入力する圧縮力の影響で, 接合部内梁付け根付近 の等価拘束圧が大きくなっている。 $\mathrm{P}$ シリーズに関しては接合部の 表面，内部ともに等価拘束圧が大きな領域がまばらであり，プレス トレスを導入した場合でも，平面十字形架構の場合はさほど大きな 拘束効果は得られないことがわかる。試験体 UP12-2 においては, 接 合部中央で等価拘束圧が際立って大きな箇所が存在するが，これは コンクリートが圧壊した（4.3 節参照）ことにより斜め方向の圧縮 応力が卓越しなくなり，偏差応力成分が小さくなったためだと考え られる。一方 S シリーズは, 接合部表面, 内部ともに高い等価拘束
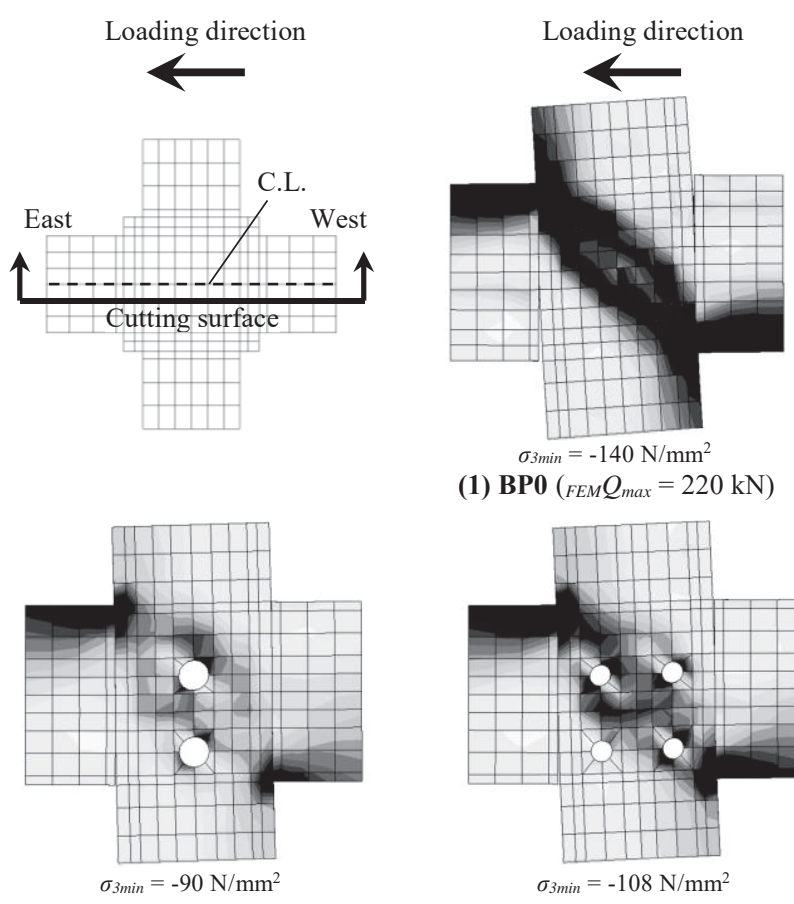

(2) UP12-2 ( FEM $\left.Q_{\max }=114 \mathrm{kN}\right)$

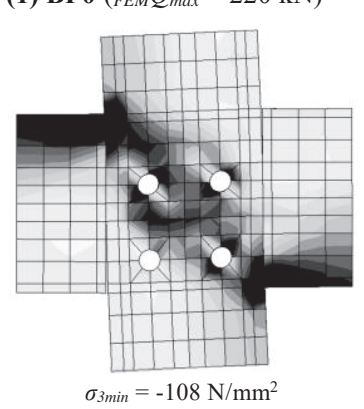

(3) UP12-4 ( FEM $\left._{\max }=138 \mathrm{kN}\right)$

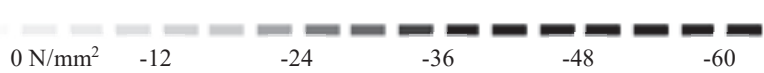

Fig. 15 Distribution of minimum principal stress at $Q_{\max }$
圧を有しており，接合部全体で良好な拘束効果が得られている。ま た, P シリーズでは斜め圧縮力が卓越する接合部内部において等価 拘束圧の消失が顕著であるのに対し，S シリーズでは圧縮ストラッ 卜内でも広範囲で高い拘束効果が現れている。したがって，3.1 節 で前述した最大耐力の向上およびその後の荷重低下挙動に関しては, 接合部コンクリートの拘束状態が大きく寄与していることがわかる。

\section{3 損傷度}

コンクリートの圧縮領域における損傷度は, Fig. 18 に示す応力 の不変量 $\xi-r$ 平面上における偏差応力成分 $r$ を用いて定義する ${ }^{9)}$ 。 すなわち, 応力の不変量 $\left(\xi_{p}, r_{p}\right)$ を有する応力点 $P$ の損傷度 $D_{f}$ は, 静水压成分 $\xi_{p}$ における Drucker-Prager 基準の子午線上の圧壊前の 偏差応力成分 $r_{f s}$ に対する $r_{p}$ の比として, $D_{f}=r_{p} / r_{f s}$ で定義する。

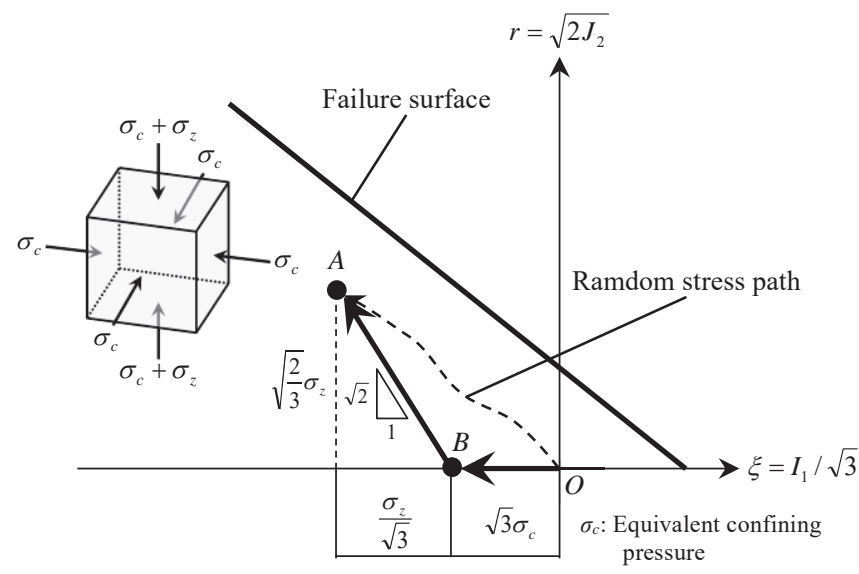

Fig. 16 Equivalent confining pressure for triaxial state of stress

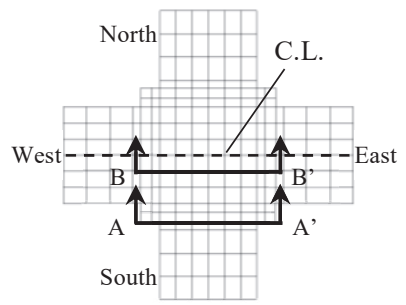

Cutting surface

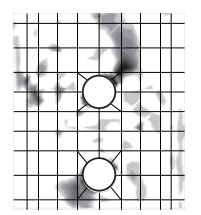

A-A' section

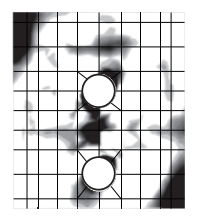

B-B' section

(2) UP12-2 ( FEM $\left._{\text {max }}=114 \mathrm{kN}\right)$

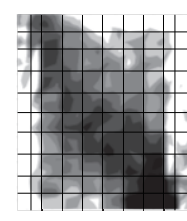

A-A' section

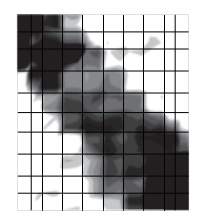

B-B' section

(4) BSO $\left({ }_{F E M} Q_{\max }=242 \mathrm{kN}\right)$

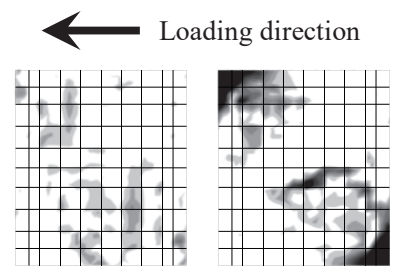

B-B' section (1) BP0 ( fEM $_{\max }=220 \mathrm{kN}$ )

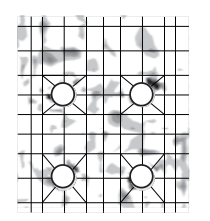

A-A' section (3) UP12-4 ( FEM Q $\left._{\max }=138 \mathrm{kN}\right)$

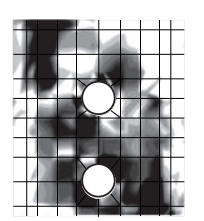

A-A' section

B-B' section

B-B' section
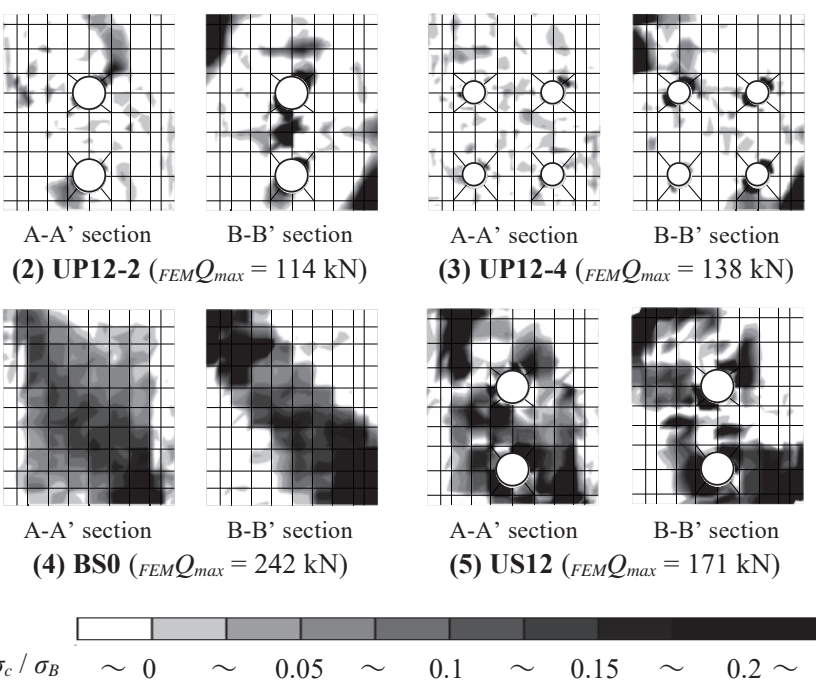

Fig. 17 Comparison of equivalent confining pressure at $Q_{\max }$ 
したがって, どの方向にも引張応力とせん断応力が現れない静水圧 軸（ $\xi$ 軸）上で 0 , 破壞曲面上で 1 となる。

Fig. 19 に, 最大耐力時における接合部の損傷度を比較して示す。 損傷度は等価拘束圧と同様に, 接合部表面および接合部内部の切断 面（A-A' 断面と B-B’ 断面）に最も近い積分点における応力状態よ り算出しており，損傷度が小さな領域を灰色，大きな領域を黒色で 示している。ここで，圧壊が生じて軟化領域に入ると積分点は破壊 曲面上にあるが，破壊曲面そのものが縮小寸るため，損傷度は見か け上減少に転じる。それ故, 圧壊後軟化領域に入った箇所は白色で 示している。Fig. 19 より, 全試験体において圧縮ストラットに沿 って損傷度が大きくなっていることがわかる。無開孔の試験体 BP0 は接合部内部の広範囲で損傷度が大きくなり, 圧壊領域が広がって いるのに対して，接合部に開孔を有する試験体 UP12-2 および UP124 では，開孔間で圧壊が生じている。これは開孔により圧縮応力を 負担する領域が局所化した影響であると考えられる。また，試験体 UP12-4 の接合部中央における圧壊領域は試験体 UP12-2 と比較して 小さくなっているため, シース管が分散している方が応力伝達にお いては有利であると考えられ，3.1 節で述べた最大耐力時の層間変 形角の差としても現れている。P シリーズと S シリーズの比較にお いては, 試験体 BS0 は BP0 と比較して接合部内部での圧壊がほとん ど生じていない。これは 4.2 節で述べたように，圧縮ストラット内 においてもコンクリートの等価拘束圧が大きく保たれたことが影響 している。一方，同じ開孔状況である試験体 UP12-2 と US12 の比較 では, 開孔間で圧壊が生じる傾向は両者に見られるものの, 試験体 US12 の損傷は接合部のより広い領域に拡がっており，せん断抵抗に 寄与した部分が大きく, 最大耐力が 5 割上昇したと考えられる。ま た，全体的な傾向として，S シリーズでは損傷が P シリーズと比較 して接合部表面にも広がっている。このことから，S シリーズでは 接合部断面内でより一様に圧縮力を負担することで損傷が分散し, 接合部中央のみでの圧縮破壊が抑制されていることがわかる。

\section{5. まとめ}

接合部における久損状況および直交梁の有無が PCaPC 造柱梁接 合部の内部応力状態および破壊メカニズムに及ぼす影響を検討する ため, 既往試験体を対象とした三次元有限要素解析を行い，以下の 知見が得られた。

1）開孔を有するアンボンド型柱梁接合部架構のせん断抵抗力が 無開孔のボンド型柱梁接合部架構と比較して低下寸る，ま た, 立体十字形架構は平面十字形架構と比較して変形性能お よび最大耐力が向上するという実験結果を, 本解析上でも再 現することができた。

2） アンボンド型柱梁接合部とボンド型柱梁接合部における応力 伝達機構を最小主応力分布に基づいて考察し, アンボンド型 架構では開孔部を避けるように圧縮ストラットが形成されて いることを確認した。

3）各積分点レベルにおける三軸応力状態に基づく等価拘束圧と 損傷度を用いて，接合部における開孔状況，直交梁およびプ レストレスが接合部コンクリートの拘束状態とせん断圧縮破 壊に及ぼす影響を検討し，1）で記述した結果の要因を明らか にした。

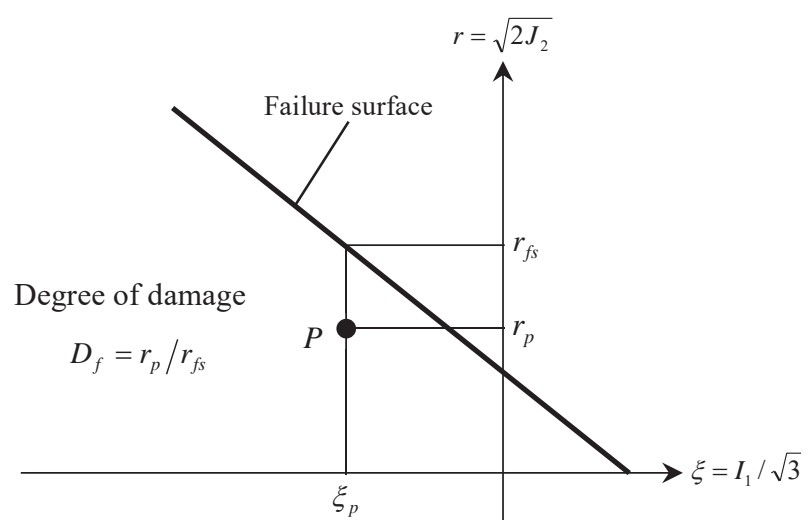

Fig. 18 Definition of degree of damage

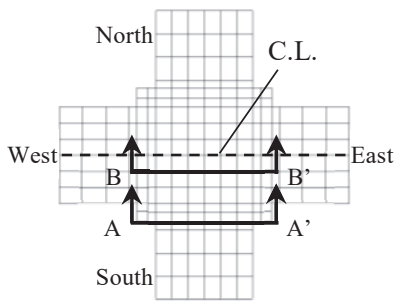

Cutting surface

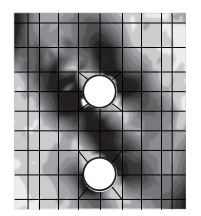

A-A' section (2) UP12-2 ( $\left.\mathrm{FEM}_{\text {max }}=114 \mathrm{kN}\right)$

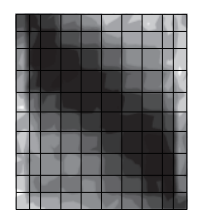

A-A' section

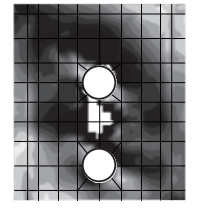

B-B' section

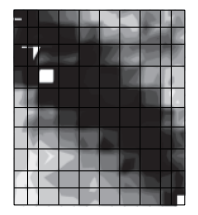

B-B' section

(4) BSO $\left(F \in M Q_{\max }=242 \mathrm{kN}\right)$

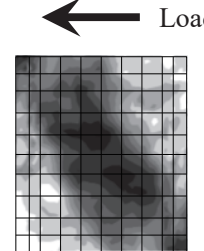

A-A' section (1) $\mathrm{BPO}\left(\mathrm{Fm}^{\mathrm{m}} \mathrm{max}=\right.$

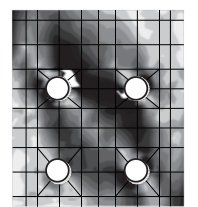

A-A' section (3) UP12-4 (FEM $\left.Q_{\max }=138 \mathrm{kN}\right)$

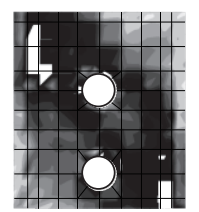

A-A' section (5) US12 ( F M $_{\text {max }}=171 \mathrm{kN}$ )

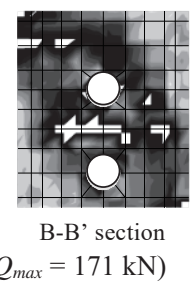

$0 \sim 0.1 \sim 0.2 \sim 0.3 \sim 0.4 \sim 0.5 \sim 0.6 \sim 0.7 \sim 0.8 \sim 0.9 \sim 1$ Softening

Fig. 19 Comparison of degree of damage at $Q_{\max }$

謝辞

本研究で用いた試験体の実験は首都大学東京大型実験棟で行いま した。首都大学東京北山和宏教授をはじめ, 多くの方々にご協力頂 きました。ここに厚く御礼申し上げます。

\section{参考文献}

1) Suzuki, A. Beniya, N. Kashiwazaki, T. and Noguchi, H.: Study on the Shear Performances of PC Interior Beam-Column Joints (Part1, Part2 and Part3), Summaries of technical papers of annual meeting Architectural Institute of Japan, C-2, pp.841 846, 1997.9 (in Japanese)

鈴木晶子, 紅谷信行, 柏崎隆志, 野口博 : PC 構造内柱・梁接合部の也 几断性状に関する研究（その 1）（その 2）（その3）, 日本建築学会大会 学術講演梗概集, C-2, pp.841 846, 1997.9

2) Architectural Institute of Japan: Design Guidelines for Earthquake Resistant Reinforced Concrete Buildings Based on Inelastic Displacement Concept, 
1999 (in Japanese)

日本建築学会 : 鉄筋コンクリート造建物の勒性保証型耐震設計指針・同 解説, 1999

3) Adachi, K. and Kishida, S.: Mechanical property of PCaPC frame assembled by post-tensioning tendons under 3 directional forces, Proceedings of the Japan Concrete Institute, Vol.30, No.3, pp.313-318, 2008.7 (in Japanese) 足立幸多朗, 岸田慎司 : 3 方向外力を受けるプレキャストプレストレス トコンクリート圧着骨組の力学性状に関する研究，コンクリート工学 年次論文集，Vol.30，No.3，pp.313-318，2008.7

4) Adachi, K. and Kishida, S.: Influence given to joint shear Force of Volumn loss by presence of grout material of PCaPC Beam-Column Joint Assembled by Post Tensioning, Summaries of technical papers of annual meeting Architectural Institute of Japan, C-2, pp.861 862, 2009.7 (in Japanese) 足立幸多朗, 岸田慎司：PCaPC 造柱梁接合部のグラウト材の有無によ る断面欠損の接合部せん断強度に与える影響, 日本建築学会大会学術 講演梗概集，C-2，pp.861〜862，2009.7

5) Yamashita, K. Tomiyama, Z. Kishida, S. and Tajima, Y.: Effect of vacant space to sheath tubes to Maximum story shear and shear strength of beam-column joint in the unbonded precast prestressed concrete frame assembled by post tensioning steel bars (Part1 and Part2), Summaries of technical papers of annual meeting Architectural Institute of Japan, Structures-4, pp.715 718, 2015.9 (in Japanese)

山下海斗, 冨山善太, 岸田慎司, 田島祐之 : シース管による空隙がアン ボンド PCaPC 造十字形架構の最大耐力と接合部せん断強度に及ぼす影 響 (その 1)（その 2), 日本建築学会大会学術講演梗概集, 構造IV, pp.715 $\sim 718, \quad 2015.9$

6) Tajima, Y. Kishida, S. and Tomiyama, Z.: SEISMIC PERFORMANCE OF UNBONDED PRECAST PRESTRESSED CONCRETE BEAM-COLUMN JOINTS CAUSED VOLUME LOSS IN JOINT PANEL BY SHEATH TUBES, Proceedings of the Japan Concrete Institute, Vol.38, No.2, pp.337-342, 2016.7 (in Japanese)

田島祐之, 岸田慎司, 冨山善太 : アンボンド PCaPC 造架構における直 交梁の有無とシース管の空隙に着目した接合部せん断性状，コンクリ 一ト工学年次論文集, Vol.38, No.2, pp.337-342, 2016.7

7) Terada, Y. and Kishida, S.: Analytical Study for Precast-Prestressed Concrete Beam-Column Joints Assembled by Post-Tensioning, Summaries of technical papers of annual meeting Architectural Institute of Japan, C-2, pp.859 860, 2009.7 (in Japanese)

寺田佳史, 岸田慎司 : 压着接合されたプレストレストコンクリート造柱 梁接合部の解析的研究, 日本建築学会大会学術講演梗概集, C-2, pp.859 $\sim 860, \quad 2009.7$

8) Mizuno, E. and Hatanaka, S. : DEVELOPMENT OF A STRAIN-SOFTENING TYPE CONCRETE CONSTITUTIVE MODEL AND 3-D FEM ANALYSES FOR CONFINED CONCRETE, Proceedings of JSCE, No.571, V-36, pp.185 $\sim 197,1997.8$ (in Japanese)

水野英二, 畑中重光: コンクリートのひずみ軟化型構成モデルの開発と コンファインドコンクリートの三次元有限要素解析, 土木学会論文集, No.571, V-36, pp.185〜197, 1997.8

9) Yoshida, Y. Mizuno, E. and Hatanaka, S.: FEM Analysis on Stress and Damage States inside Confined Concrete Cylinders, Proceedings of the Japan Concrete Institute, Vol.24, No.2, pp.97-102, 2002.6 (in Japanese)

吉田幸夫, 水野英二, 畑中重光 : 円形コンファインドコンクリート内部 の応力と損傷状態に関する FEM 解析, コンクリートエ学年次論文集, Vol.24, No.2, pp.97-102, 2002.6

10) Murakami, K.: A CONSIDERATION ON CALCULATION OF ULTIMATE SHEAR STRENGTH OF REINFORCED CONCRETE BEAM, Journal of Structural and Construction Engineering (Transactions of AIJ), No.533, pp.143 $\sim 150,2000.7$ (in Japanese)
村上聖 : 鉄筋コンクリート梁の終局せん断強度算定式に関する一考察, 日本建築学会構造系論文集，No.533，pp.143～150，2000.7

11) Shinohara, Y. Boku, S. Ohya, F. and Watanabe, H.:EFFECT OF ACTIVE CONFINEMENT ON SHEAR BEHAVIOR FOR HIGH-STRENGTH CONCRETE COLUMNS PRESTRESSED LATERALLY, Journal of Structural and Construction Engineering (Transactions of AIJ), No.613, pp.113 120, 2007.5 (in Japanese)

篠原保二, 朴世万, 大家史, 渡部洋 : 横方向プレストレスを導入した高 強度コンクリート柱のせん断挙動に及ぼす能動的拘束効果, 日本建築 学会構造系論文集, No.613, pp.113～120, 2007.5

12) Takamori, N. Assa, B. B. Nishiyama, M. and Watanabe, F.: Idealization of Stress-Strain Relationship of Confined Concrete, Proceedings of the Japan Concrete Institute, Vol.18, No.2, pp.395-400, 1996.6 (in Japanese)

高森直樹, Benny Bermi Assa，西山峰広，渡邊史夫 : 横拘束コンクリー トの応力度一ひずみ度関係定式化に関する基礎的実験研究，コンクリ 一ト工学年次論文集，Vol.18，No.2，pp.395-400，1996.6

13) Chen, W. F.: Plasticity in Reinforced Concrete, McGraw-Hill Book Company, 1982

14) Shinohara, Y. Yasube, T. and Furumura, F.: EFFECT OF NOTCH DEPTH, LOADING RATE, AGGREGATE SIZE, WATER/CEMENT RATIO, LOADING METHOD, CURING AND AGE UPON TENSION SOFTENING PROPERTIES OF CONCRETE IN BEND TESTS, Journal of Structural and Construction Engineering (Transactions of AIJ), No.442, pp.13 22, 1992.12 (in Japanese)

篠原保二, 安部武雄, 古村福次郎：ノッチ深さ, 載荷速度, 骨材寸法, 水セメント比, 載荷法, 養生および材令がコンクリートの曲げ試験体の 引張軟化特性に及ぼす影響, 日本建築学会構造系論文報告集, No.442, pp.13 22, 1992.12

15) Shinohara, Y. and Kanako, M.: COMPRESSIVE SHEAR BEHAVIOR IN FRACTURE PROCESS ZONE OF CONCRETE, Journal of Structural and Construction Engineering (Transactions of AIJ), No.525, pp.1 6, 1999.11 (in Japanese)

篠原保二, 金子葉: コンクリートの破壊進行領域における圧縮せん断挙 動に関する実験的研究, 日本建築学会構造系論文集, No.525, pp.1〜6, 1999.11

16) Muguruma, H. Morita, S. and Tomita, K.: FUNDAMENTAL STUDY ON BOND BETWEEN STEEL AND CONCRETE (Part 1, Basic Laws of Bond Stress Distribution II), Transactions of the Architectural Institute of Japan, No.132, pp.1 6, 1967.2 (in Japanese)

六車熙, 森田司郎, 富田幸次郎 : 鋼とコンクリートの付着に関する基礎 的研究（I 付着応力分布について）- (II), 日本建築学会論文報告集, No.132, pp. $1 \sim 6, \quad 1967.2$

17) Korenaga, T. and Watanabe, H.: FLEXURAL ANALYSIS METHOD OF PRECAST PRESTRESSED CONCRETE BEAMS CONSIDERING BONDSLIP CHARACTERISTICS OF PRESTRESSING STEELS, Journal of Structural and Construction Engineering (Transactions of AIJ), No.536, pp.143 $\sim 150,2000.10$ (in Japanese)

是永健好, 渡辺英義 : PC 鋼材の付着すべりを考慮したプレキャスト PC 梁の曲げ変形解析法, 日本建築学会構造系論文集, No.536, pp. $143 \sim 150$, 2000.10

18) Architectural Institute of Japan: Standard for Structural Design and Construction of Prestressed Concrete Structures, 1998 (in Japanese) 日本建築学会 : プレストレストコンクリート設計施工規準・同解説, 1998 


\title{
EFFECT OF OPENINGS THROUGH SHEATH ON SHEAR BEHAVIORS \\ OF BEAM-COLUMN JOINT IN POST-TENSIONED PRECAST FRAME
}

\author{
Kaito YAMASHITA* , Yasuji SHINOHARA** and Shinji KISHIDA*** \\ * Grad. Student, Dept. of Environmental Sci. and Tech., Tokyo Institute of Technology \\ ** Assoc. Prof., Laboratory for FIRST, Tokyo Institute of Technology, Dr. Eng. \\ *** Prof., Dept. of Architecture, Faculty of Engineering, Shibaura Institute of Technology, Dr. Eng.
}

\begin{abstract}
A post-tensioned precast structure is expected to reduce a structural damage by concentrating a deformation in a pressure connection between beam and column. Furthermore, the post-tensioned precast structure is also advantageous from the precast construction viewpoint, especially without grouting into a sheath. Previous test results showed that a shear strength of a beam-column joint decreased with increasing a ratio of opening to the joint volume which depends on the size and the number of sheaths to go prestressing bars through.

To investigate the effect of the opening due to sheaths on the shear behaviors of the beam-column joints, 3-D finite element analyses were conducted on post-tensioned precast frames which are previously tested specimens. The experiments were performed on two types of specimens, plane cross-shaped joints (hereinafter referred to as the plane specimen) and space joints that additional beams were orthogonally installed (hereinafter referred to as the space specimen). These specimens were cut from a whole structure, and the common factors are the shear span of column and beam $(1.415 \mathrm{~m}$ and $1.6 \mathrm{~m}$, respectively), the cross-sectional dimensions of column and beam $(350 \mathrm{~mm} \times 350 \mathrm{~mm}$ and $250 \mathrm{~mm} \times 400 \mathrm{~mm}$, respectively), the bar arrangements (12-D25 (SD490) +2-D10(SD345) @90 for column, 4-D13 (SD345) +2-
\end{abstract} D10(SD345) @100 for beam, and 2-D10(KSS785) for joint), and the axial load ratio (0.13). The specimens were designed to reach shear failure at the beam-column joints before the beams fail, in accordance with design guidelines of AIJ. For this reason, the concrete strength of beams doubled $\left(\sigma_{B}=70-85 \mathrm{~N} / \mathrm{mm}^{2}\right)$. The prestressing bars (SBPD for bonded specimen by grouting and SBPR for unbonded specimen by opening) having a diameter of $36 \mathrm{~mm}$ were inserted into the sheaths and the prestressing were introduced up to the ratio of $0.13-0.17$ to an axial concrete capacity of the beam. The test parameters are diameters and arrangement of sheaths and the ratio of opening to the joint volume are 0 (by grouting) to $12 \%$. All of the specimens resulted in shear failure in the beam-column joint.

The pressing and detaching behaviors in the connection between beam and column were modeled with an interface element having an appropriate properties. The concrete was modeled with a solid element and a Drucker-Prager criterion having 15 and 20 degrees of internal friction angle depending on the concrete strength was adopted for the compressive failure, and the linear softening behavior was assumed after maximum strength. Multidirectional crack models having a threshold value of 60 degrees were used for concretes, and the shear stiffness was reduced with increasing a crack width. All reinforcing bars were modeled with embedded elements and assumed as a bi-linear behavior. The prestressing bars were modeled with truss elements, and furthermore, for the PC bars bonded by grouting, interface elements were also used to represent a bond-slip relationship.

The relations of the shear force and drift angle, the cracking patterns, and the behaviors of reinforcement which were obtained from the analysis were roughly consistent with the test results. The compressive damage and confining effect in the beam-column joints were numerically estimated based on the 3-D stress state. Analytical results that the shear strength of the beam-column joint decreased considerably with increasing opening ratio for the plane specimen without beams installed orthogonally. If, however, the orthogonal beams were installed, the shear strength of the beam-column joint increased by $20 \%$ and the decrease in shear strength due to opening was softened when compared with the plane specimen because a high confining pressure was generated around the beam-column joint of the space specimen and the effect of the concrete strength was reduced. 